\title{
Carneic Acids from an Endophytic Phomopsis sp. as Dengue Virus Polymerase Inhibitors
}

Laure-Anne Peyrat, ${ }^{\dagger}$ Véronique Eparvier, ${ }^{\dagger}$ Cécilia Eydoux, ${ }^{\ddagger}$ Jean-Claude Guillemot, ${ }^{\ddagger}$ Marc Litaudon, ${ }^{*}{ }^{\dagger}$ and Didier Stien $*, \S$

†Université Paris-Saclay, CNRS, Institut de Chimie des Substances Naturelles, UPR 2301, 91198, Gif-sur-Yvette, France

${ }^{\ddagger}$ Centre de Recherche Architecture et Fonction des Macromolécules Biologiques, UMR 7257 CNRS, Aix-Marseille Univ., 163 Avenue de Luminy, 13288-Marseille Cedex 09, France

${ }^{\S}$ Sorbonne Université, CNRS, Laboratoire de Biodiversité et Biotechnologies Microbiennes, USR3579, Observatoire Océanologique, 66650 Banyuls-sur-mer, France 
Thirteen carneic acids were isolated from the fungal endophyte Phomopsis sp. SNB-LAP1-7-32. Their structures were identified by mass spectrometry and extensive one- and two-dimensional NMR spectroscopy and through comparison with data reported in the literature. Compounds 113 were investigated for their antipolymerase activities against DENV polymerase and Zika NS5. Five of them exhibited significant inhibition of dengue polymerase with $\mathrm{IC}_{50} \mathrm{~s}$ in the 10 to $20 \mu \mathrm{M}$ range without cytotoxicity. None inhibited Zika virus NS5 protein. 
Endophytes are microorganisms growing intra- and/or intercellularly in the tissues of their host plant without causing symptoms. These microorganisms, either bacteria or fungi, can spend all or part of their life cycle inside the tissues of their host. ${ }^{1}$ They contribute to the host's protection from biotic and abiotic stress factors. Endophytes are an important source of bioactive natural products and can be considered a source of economic potential in the agrochemical and pharmaceutical industries. Since the discovery in 1993 of paclitaxel in Taxomyces brevifolia, ${ }^{2}$ a fungal endophyte associated with the phloem of the Pacific yew, Taxus brevifolia, endophytes have captured the attention of many microbiologists and chemists, and the discovery of new compounds endowed with antibacterial, antiviral, antifungal, cytotoxic, and antiprotozoal properties has increased exponentially. ${ }^{3-8}$

Recently, our group screened extracts from 1500 tropical plants using a dengue replicon virus-cell-based assay. The results were examined from a phylogenic perspective, leading to the selection of several species of the Diospyros genus for further investigation. ${ }^{9,10}$ A series of antiviral ursane- and lupane-type triterpenoids were identified from D. glans and D. carbonaria. Thereafter, we undertook a study of endophytic fungi associated with $D$. carbonaria, a species growing in dense rainforest in French Guiana. Thirty-eight fungi belonging to 5 genera were isolated from the leaves and bark of this species, among which a strain identified by sequencing as Phomopsis sp. exhibited the most potent anti-dengue activity. ${ }^{10}$ Phomopsis (teleomorph Diaporthe) species are ubiquitous as endophytes of many hosts worldwide. They also comprise phytopathogens causing cankers, root and fruit rots, leaf spots decay, blights and wilts on a wide range of plant hosts. ${ }^{11}$

Our initial intention was to discover analogous metabolites in D. carbonaria and its endophytes. We discovered that the antiviral betulinic acid was indeed present in both the plant 
and its endophyte Phomopsis sp. SNB-LAP1-7-32, although the capacity of the fungus to biosynthesize betulinic acid faded upon subculturing. ${ }^{10}$ Nevertheless, dengue virus replication inhibitory potential remained in the fungal extract. We therefore embarked upon investigating Phomopsis sp. SNB-LAP1-7-32 secondary metabolites and evaluating their anti-dengue potential. Similar to dengue virus, Zika virus belongs to the Flaviviridae family and possesses the same vector, a similar genome and the same replication mechanism. To find new viral paninhibitors, compounds isolated from Phomopsis sp. have also been evaluated against Zika virus.

\section{- RESULTS AND DISCUSSION}

Phomopsis sp. (SNB-LAP1-7-32) was isolated from the leaves of Diospyros carbonaria Benoist. It was cultivated on potato dextrose agar (PDA), and the ethyl acetate extract of the culture exhibited a significant inhibition of dengue virus replication $(60 \%$ at $10 \mu \mathrm{g} / \mathrm{mL})$ without cytotoxicity $(100 \%$ of viable COS cells at $10 \mu \mathrm{g} / \mathrm{mL})$. The extract was subjected to $\mathrm{C}_{18}$ flash chromatography to yield 8 fractions, which were evaluated in the dengue polymerase assay (Supporting information, Table S1). Most of the fractions showed at least some polymeraseinhibiting activity, and fractions 6, 7 and 8 exhibited a clear dose-related effect. All fractions were eventually submitted to semipreparative HPLC, which yielded 13 new carneic acids (1-13). Betulinic acid was isolated from fraction $8 .^{10}$ 


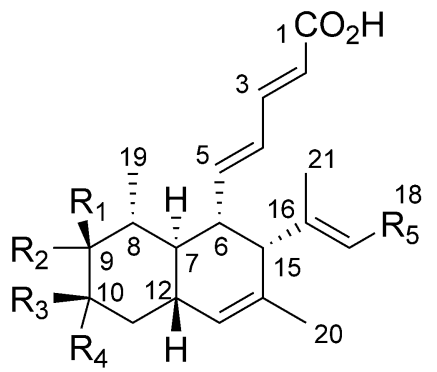

\begin{tabular}{|c|c|c|c|c|c|}
\hline arneic acid & $\mathrm{R}_{1}$ & $\mathrm{R}_{2}$ & $\mathrm{R}_{3}$ & $\mathrm{R}_{4}$ & $\mathrm{R}_{5}$ \\
\hline$C(1)$ & $\mathrm{H}$ & $\mathrm{H}$ & $\mathrm{H}$ & $\mathrm{OH}$ & $\mathrm{CH}_{3}$ \\
\hline$D(2)$ & $\mathrm{H}$ & $\mathrm{H}$ & $\mathrm{OH}$ & $\mathrm{H}$ & $\mathrm{CH}_{3}$ \\
\hline$E(3)$ & $\mathrm{H}$ & $\mathrm{H}$ & OAc & $\mathrm{H}$ & $\mathrm{CH}_{3}$ \\
\hline $\mathrm{F}(4)$ & $\mathrm{H}$ & $\mathrm{H}$ & $=c$ & & $\mathrm{CH}_{3}$ \\
\hline G (5) & $\mathrm{H}$ & $\mathrm{H}$ & $\mathrm{H}$ & $\mathrm{OH}$ & $\mathrm{CH}_{2} \mathrm{OH}$ \\
\hline$H(6)$ & $\mathrm{H}$ & $\mathrm{H}$ & $\mathrm{OH}$ & $\mathrm{H}$ & $\mathrm{CH}_{2} \mathrm{OH}$ \\
\hline$I(7)$ & $\mathrm{OH}$ & $\mathrm{H}$ & $\mathrm{H}$ & $\mathrm{H}$ & $\mathrm{CH}_{2} \mathrm{OH}$ \\
\hline$J(8)$ & $\mathrm{H}$ & $\mathrm{H}$ & $\mathrm{H}$ & $\mathrm{H}$ & $\mathrm{CH}_{2} \mathrm{OH}$ \\
\hline K (9) & $\mathrm{H}$ & $\mathrm{H}$ & $=\mathrm{c}$ & & $\mathrm{CH}_{2} \mathrm{OH}$ \\
\hline$L(10)$ & $\mathrm{H}$ & $\mathrm{H}$ & $=c$ & & $\mathrm{CH}_{2} \mathrm{OA}$ \\
\hline$M(11)$ & $\mathrm{H}$ & $\mathrm{H}$ & $\mathrm{H}$ & $\mathrm{OH}$ & $\mathrm{CH}_{2} \mathrm{OAC}$ \\
\hline$N(12)$ & $\mathrm{OH}$ & $\mathrm{H}$ & $\mathrm{H}$ & $\mathrm{H}$ & $\mathrm{CH}_{2} \mathrm{OAC}$ \\
\hline$O(13)$ & $\mathrm{H}$ & $\mathrm{OH}$ & $\mathrm{H}$ & $\mathrm{H}$ & $\mathrm{CH}_{2} \mathrm{O}$ \\
\hline
\end{tabular}

The HRESIMS of compound 1 indicated a molecular formula $\mathrm{C}_{21} \mathrm{H}_{30} \mathrm{O}_{3}$, a compound with 7 degrees of unsaturation. The ${ }^{1} \mathrm{H}$ NMR data (Table 1) revealed four methyl groups at $\delta_{\mathrm{H}}$ $1.62,1.58,1.50$, and 0.91 and six vinylic protons at $\delta_{\mathrm{H}} 7.35,6.13,6.10,5.79,5.25$, and 5.22. The ${ }^{13} \mathrm{C}$ NMR (Table 2) and HSQC spectra revealed the presence of a carboxylic acid $\left(\delta_{\mathrm{C}} 171.6\right)$ $\left(1689.63 \mathrm{~cm}^{-1}\right)$, eight other $\mathrm{sp}^{2}$ carbons $\left(\delta_{\mathrm{C}} 152.2,147.1,134.5,133.5,127.2,125.7,124.3\right.$, and 117.9), and seven $\mathrm{sp}^{3}$ methines $\left(\delta_{\mathrm{C}} 69.8,50.0,44.9,34.9,46.9,42.3,40.9\right.$, and 56.7), one of which is oxygenated (C-10). This information suggested that compound $\mathbf{1}$ could be an analogue of carneic acids A and B, described by Quang et al. (Figure S1). ${ }^{12,13}$ The COSY spectrum revealed two spin systems, one from C-2 to C-15, including the methyl substituents C-19 and C20, and the second from C-17 to C-18 and C-21 (Figure 1). The spin system from C-2 to C-15 allowed building most of the decaline skeleton. Long-range COSY correlations Me-21/H-17 and Me-21/ $\mathrm{H}_{3}-18$, and between Me-20 and $\mathrm{H}-12, \mathrm{H}-13$ and $\mathrm{H}-15$, along with HMBC correlations 
from $\mathrm{H}_{3}-20$ and $\mathrm{H}_{3}-21$ to their respective neighboring carbons, suggested that the methylpropyl unit was linked to $\mathrm{C}-15$. HMBC correlations also confirmed the ring junction with $\mathrm{C}-12$, as depicted in Figure 1. The H-2-H-3 coupling constant $(J=15.3 \mathrm{~Hz})$ allowed us to ascertain the $E$ configuration of the C-2-C-3 double bond. The magnetic proximity of protons $\mathrm{H}-4$ and $\mathrm{H}-5$ induced second-order figures and precluded the reading of the H-4-H-5 coupling constant. At this point, the configuration of the C-4-C-5 double bond was uncertain. However, comparison of ${ }^{1} \mathrm{H}$ and ${ }^{13} \mathrm{C}$ spectra in the 13 carneic acid series indicated that the $\mathrm{C}-4-\mathrm{C}-5$ double bond was always $E$. For example, the H-4-H-5 coupling constant was $15.3 \mathrm{~Hz}$ in compound 4. 
Table 1. ${ }^{1} \mathrm{H}$ NMR Spectroscopic Data $\left(\mathrm{CDCl}_{3}\right)$ for Compounds 1-7.

\begin{tabular}{|c|c|c|c|c|c|c|c|}
\hline Position & $\overline{1^{a}}$ & $2^{\mathrm{a}}$ & $\mathbf{3}^{\mathrm{b}}$ & $\overline{4^{\mathrm{a}}}$ & $\mathbf{5}^{\mathrm{a}}$ & $6^{\mathrm{a}}$ & $7^{\mathrm{a}}$ \\
\hline 2 & $5.79 \mathrm{~d}(15.3)$ & $5.79 \mathrm{~d}(15.3)$ & $5.79 \mathrm{~d}(15.2)$ & $5.83 \mathrm{~d}(15.3)$ & 5.80 brd (15.3) & 5.83 brd (14.5) & $5.78 \mathrm{~d}(15.3)$ \\
\hline 3 & $7.35 \mathrm{~m}$ & $\begin{array}{l}7.35 \text { brddd } \\
(15.3,6.9,3.1)\end{array}$ & $7.36 \mathrm{~m}$ & $7.36 \mathrm{dd}(15.3,10.9)$ & 7.33 brdd $(9.8,15.2)$ & $7.18 \mathrm{dd}(14.5,10.7)$ & $7.33 \mathrm{~m}$ \\
\hline 4 & $6.10 \mathrm{~m}$ & $6.122 \mathrm{~m}$ & $6.15 \mathrm{~m}$ & $6.20 \mathrm{dd}(15.3,10.9)$ & $6.13 \mathrm{~m}$ & $6.17 \mathrm{dd}(15.0,10.7)$ & $6.13 \mathrm{~m}$ \\
\hline 5 & $6.13 \mathrm{~m}$ & $6.120 \mathrm{~m}$ & $6.12 \mathrm{~m}$ & $6.08 \mathrm{dd}(15.3,10.6)$ & $6.12 \mathrm{~m}$ & $6.07 \mathrm{dd}(15.0,10.5)$ & $6.15 \mathrm{~m}$ \\
\hline 6 & $\begin{array}{l}2.39 \text { brtd } \\
(10.4,5.8)\end{array}$ & $2.49 \mathrm{~m}$ & $2.49 \mathrm{~m}$ & $2.48 \operatorname{brtd}(10.6,6.0)$ & $2.45 \operatorname{brtd}(10.3,6.3)$ & $2.52 \mathrm{~m}$ & $2.51 \mathrm{~m}$ \\
\hline 7 & $1.20 \mathrm{q}(10.4)$ & $1.23 \mathrm{brq}(10.2)$ & 1.26 brq (10.2) & 1.44 brq (10.2) & $1.20 \mathrm{~d}(10.3)$ & $1.29 \mathrm{brq}(10.3)$ & 1.32 brq (10.2) \\
\hline 8 & $1.35 \mathrm{~m}$ & $1.65 \mathrm{~m}$ & $1.58 \mathrm{~m}$ & 1.81 brdsext $(9.0,6.8)$ & $1.36 \mathrm{~m}$ & $1.65 \mathrm{~m}$ & $1.18 \mathrm{~m}$ \\
\hline 9 & $\begin{array}{l}\text { a : } 1.09 \text { brq } \\
(11.9) \\
\text { b: } 1.92 \text { brd } \\
(12.6)\end{array}$ & $\begin{array}{l}\text { a: } 1.32 \text { brtd } \\
(14.0,2.3) \\
\text { b: } 1.73 \text { brdq } \\
(14.4,2.3)\end{array}$ & $\begin{array}{l}\text { a: } 1.29 \mathrm{~m} \\
\text { b: } 1.81 \text { brdq }(14.6,3.0)\end{array}$ & $\begin{array}{l}\text { a: } 2.05 \mathrm{dd}(14.5,6.8) \\
\text { b: } 2.57 \mathrm{dd}(14.5,6.8)\end{array}$ & $\begin{array}{l}\text { a: } 1.09 \mathrm{q}(11.7) \\
\text { b: } 1.93 \mathrm{~m}\end{array}$ & $\begin{array}{l}\text { a: } 1.30 \mathrm{~m} \\
\text { b: } 1.72 \text { brdq }(14.1,2.5)\end{array}$ & $3.17 \operatorname{brtd}(10.1,4.6)$ \\
\hline 10 & $\begin{array}{l}3.70 \mathrm{brtt} \\
(10.9,4.4)\end{array}$ & $\begin{array}{l}4.14 \text { brquint } \\
(2.3)\end{array}$ & 5.07 brquint (2.9) & & $3.70 \mathrm{~m}$ & $4.04 \operatorname{brt}(2.5)$ & $\begin{array}{l}\text { a: } 1.40 \mathrm{brqd}(12.0,3.2) \\
\text { b: } 2.04 \mathrm{~m}\end{array}$ \\
\hline 11 & $\begin{array}{l}\text { a: } 1.11 \mathrm{brq} \\
(10.8) \\
\text { b: } 2.01 \mathrm{brd} \\
(11.9)\end{array}$ & $\begin{array}{l}\text { a: } 1.36 \text { brtd } \\
(13.5,2.1) \\
\text { b: } 1.79 \text { brdq } \\
(13.5 .2 .2)\end{array}$ & $\begin{array}{l}\text { a: } 1.35 \operatorname{brtd}(13.8,2.6) \\
\text { b: } 1.89 \operatorname{brdq}(13.8,2.9)\end{array}$ & $\begin{array}{l}\text { a: } 2.04 \operatorname{brt}(14.9) \\
\text { b: } 2.47 \operatorname{brd}(14.9)\end{array}$ & $\begin{array}{l}\text { a: } 1.10 \mathrm{q}(11.9) \\
\text { b: } 2.01 \text { brd (11.9) }\end{array}$ & $\begin{array}{l}\text { a: } 1.36 \operatorname{td}(13.5,2.5) \\
\text { b: } 1.78 \text { brdq }(13.5,2.5)\end{array}$ & $\begin{array}{l}\text { a: } 1.19 \mathrm{~m} \\
\text { b: } 1.77 \mathrm{~m}\end{array}$ \\
\hline 12 & $\begin{array}{l}1.79 \mathrm{brt} \\
(11.1)\end{array}$ & 2.27 brt (11.3) & $2.16 \mathrm{~m}$ & $2.33 \mathrm{~m}$ & 1.80 brt (11.7) & 2.28 brt (11.6) & $1.79 \mathrm{~m}$ \\
\hline 13 & $5.25 \mathrm{~s}$ & 5.20 brs & $5.19 \mathrm{brs}$ & 5.26 brs & 5.29 brs & $5.25 \mathrm{brs}$ & $5.31 \mathrm{brs}$ \\
\hline 15 & 2.53 brd (5.3) & 2.52 brd (5.4) & $2.53 \mathrm{brd}(5.6)$ & 2.62 brd (5.7) & 2.57 brd (5.4) & 2.56 brd (4.9) & 2.56 brd (5.5) \\
\hline 17 & $5.22 \mathrm{brq}(6.7)$ & $5.21 \mathrm{brq}(6.7)$ & $5.21 \mathrm{brq}(6.7)$ & $5.25 \mathrm{brq}(6.8)$ & 5.41 brt (6.5) & 5.38 brt (6.3) & 5.41 brt (6.4) \\
\hline 18 & $1.62 \mathrm{~d}(6.7)$ & $1.62 \mathrm{~d}(6.7)$ & $1.61 \mathrm{~d}(6.7)$ & 1.64 brd (6.8) & $\begin{array}{l}\text { a: } 4.21 \mathrm{dd}(12.6,6.8) \\
\text { b: } 4.24 \mathrm{dd}(12.6,6.8)\end{array}$ & $\begin{array}{l}\text { a: } 4.14 \mathrm{dd}(13.0,6.1) \\
\text { b: } 4.17 \mathrm{dd}(13.0,6.6)\end{array}$ & $\begin{array}{l}\text { a: } 4.20 \mathrm{dd}(12.8,6.6) \\
\text { b: } 4.25 \mathrm{dd}(12.8,6.6)\end{array}$ \\
\hline 19 & $0.91 \mathrm{~d}(6.3)$ & $0.86 \mathrm{~d}(6.3)$ & $0.86 \mathrm{~d}(6.4)$ & $0.93 \mathrm{~d}(6.6)$ & $0.91 \mathrm{~d}(6.1)$ & $0.89 \mathrm{~d}(6.4)$ & $1.03 \mathrm{~d}(6.2)$ \\
\hline 20 & $1.50 \mathrm{brs}$ & $1.50 \mathrm{~s}$ & $1.50 \mathrm{brs}$ & 1.54 brs & $1.53 \mathrm{~s}$ & $1.54 \mathrm{~s}$ & $1.53 \mathrm{~s}$ \\
\hline 21 & $1.58 \mathrm{brs}$ & $1.58 \mathrm{~s}$ & $1.57 \mathrm{~s}$ & $1.61 \mathrm{brs}$ & $1.65 \mathrm{~s}$ & $1.66 \mathrm{~s}$ & $1.66 \mathrm{~s}$ \\
\hline 23 & & & $2.05 \mathrm{~s}$ & & & & \\
\hline
\end{tabular}


Table 2. ${ }^{13} \mathrm{C}$ NMR Spectroscopic Data $\left(\mathrm{CDCl}_{3}\right)$ for Compounds $\mathbf{1}-\mathbf{1 3}$.

\begin{tabular}{|c|c|c|c|c|c|c|c|c|c|c|c|c|c|}
\hline Position & $1^{\mathrm{a}}$ & $2^{2^{\mathrm{a}}}$ & $3^{\mathrm{b}}$ & $\overline{4^{\mathrm{a}}}$ & $5^{5^{a}}$ & $6^{\mathrm{a}}$ & $7^{\mathrm{a}}$ & $\overline{8^{b}}$ & $9^{\mathrm{b}}$ & $1 \mathbf{1 0}^{\mathrm{b}}$ & $11^{\mathrm{b}}$ & $12^{\mathrm{b}}$ & $13^{\mathrm{b}}$ \\
\hline 1 & $171.6, \mathrm{C}$ & 171.3 & 170.8 & 171.4 & 169.4 & 170.6 & 170.9 & 170.2 & 172.2 & n.d. & 171.2 & 172.3 & 172.0 \\
\hline 2 & 117.9, CH & 117.8 & 117.5 & 118.8 & 117.6 & 115.6 & 118.3 & 117.8 & 120.2 & n.d. & 119.6 & 118.7 & 118.6 \\
\hline 3 & 147.1, CH & 147.1 & 147.2 & 146.4 & 146.4 & 144.8 & 146.8 & 147.4 & 145.5 & n.d. & 146.4 & 1465 & 146.5 \\
\hline 4 & $125.7, \mathrm{CH}$ & 125.7 & 125.7 & 127.2 & 125.9 & 127.8 & 126.2 & 126.0 & 127.6 & 128.2 & 126.2 & 125.9 & 126.0 \\
\hline 5 & $152.2, \mathrm{CH}$ & 152.5 & 152.5 & 149.2 & 150.8 & 150.5 & 151.2 & 152.4 & 148.1 & 148.2 & 150.7 & 151.0 & 150.9 \\
\hline 6 & $50.0, \mathrm{CH}$ & 50.0 & 50.0 & 49.6 & 49.3 & 51.5 & 50.3 & 50.4 & 49.0 & 49.5 & 49.7 & 49.8 & 49.8 \\
\hline 7 & $44.9, \mathrm{CH}$ & 45.7 & 45.3 & 43.5 & 44.7 & 47.0 & 43.8 & 46.0 & 43.5 & 43.9 & 45.1 & 43.5 & 43.3 \\
\hline 8 & $34.9, \mathrm{CH}$ & 30.6 & 31.3 & 34.4 & 34.7 & 32.1 & 43.8 & 36.5 & 34.5 & 34.7 & 35.2 & 43.5 & 40.2 \\
\hline 9 & $46.9, \mathrm{CH}_{2}$ & 44.1 & 40.8 & 48.8 & 46.6 & 45.2 & $76.4, \mathrm{CH}$ & 38.2 & 48.9 & 49.1 & 47.0 & $76.1, \mathrm{CH}$ & $78.1, \mathrm{CH}$ \\
\hline 10 & $69.8, \mathrm{CH}$ & 66.8 & 70.1 & $211.7, \mathrm{C}$ & 69.1 & 67.6 & $35.4, \mathrm{CH}_{2}$ & 26.6, $\mathrm{CH}_{2}$ & $212.4, \mathrm{C}$ & $211.8, \mathrm{C}$ & 69.8 & $35.0, \mathrm{CH}_{2}$ & $31.2 \mathrm{CH}_{2}$ \\
\hline 11 & $42.3, \mathrm{CH}_{2}$ & 40.1 & 37.0 & 46.8 & 42.2 & 41.2 & 31.0 & $34.0, \mathrm{CH}_{2}$ & 46.7 & 47.2 & 42.4 & 30.7 & 30.3 \\
\hline 12 & $40.9, \mathrm{CH}$ & 35.8 & 36.6 & 39.9 & 40.6 & 37.3 & 42.9 & 43.4 & 39.7 & 40.2 & 41.1 & 42.4 & 42.2 \\
\hline 13 & 127.2, CH & 127.6 & 127.1 & 125.1 & 127.7 & 129.8 & 128.3 & 129.5 & 125.8 & 126.4 & 128.3 & 128.2 & 127.7 \\
\hline 14 & $134.5, \mathrm{C}$ & 134.3 & 134.5 & 133.3 & 133.4 & 134.7 & 133.4 & 132.9 & 137.7 & 135.9 & 133.4 & 132.9 & 129.1 \\
\hline 15 & $56.7, \mathrm{CH}$ & 56.5 & 56.5 & 55.7 & 56.2 & 57.9 & 56.3 & 56.7 & 55.4 & 56.0 & 56.4 & 56.0 & 55.9 \\
\hline 16 & $133.5, \mathrm{C}$ & 133.7 & 133.6 & 135.5 & 136.8 & 137.7 & 137.3 & 137.7 & 136.7 & 139.6 & 139.8 & 139.6 & 136.9 \\
\hline 17 & $124.3, \mathrm{CH}$ & 124.2 & 124.3 & 124.5 & 129.2 & 130.6 & 129.4 & 129.4 & 129.1 & 124.9 & 124.6 & 123.9 & 129.1 \\
\hline 18 & $13.5, \mathrm{CH}_{3}$ & 13.6 & 13.6 & 13.6 & $59.2, \mathrm{CH}_{2}$ & $59.8, \mathrm{CH}_{2}$ & $59.5, \mathrm{CH}_{2}$ & $59.7, \mathrm{CH}_{2}$ & $59.0, \mathrm{CH}_{2}$ & $61.5, \mathrm{CH}_{2}$ & $61.3, \mathrm{CH}_{2}$ & $61.2, \mathrm{CH}_{2}$ & $59.1, \mathrm{CH}_{2}$ \\
\hline 19 & $22.8, \mathrm{CH}_{3}$ & 22.8 & 22.7 & 23.4 & 22.4 & 23.6 & 18.2 & 23.6 & 23.4 & 23.8 & 23.0 & 18.0 & 17.8 \\
\hline 20 & $21.3, \mathrm{CH}_{3}$ & 21.4 & 21.4 & 21.4 & 20.9 & 22.0 & 21.3 & 21.6 & 21.6 & 21.8 & 21.6 & 21.3 & 21.32 \\
\hline 21 & 17.6, $\mathrm{CH}_{3}$ & 17.7 & 17.6 & 17.9 & 18.0 & 19.0 & 18.4 & 18.3 & n.d. & 18.8 & 18.3 & 18.2 & 18.1 \\
\hline 22 & & & $170.6, \mathrm{C}$ & & & & & & & 171.5 & 171.2 & 171.3 & 171.0 \\
\hline 23 & & & $21.4, \mathrm{CH}_{3}$ & & & & & & & 21.3 & 21.2 & 21.0 & 21.29 \\
\hline
\end{tabular}

Unless otherwise specified, the carbon type was identical to that of compound 1. ${ }^{a} \delta_{\mathrm{C}}$, type, spectrum was recorded at $125 \mathrm{MHz}$. ${ }^{\mathrm{b}} \delta_{\mathrm{C}}$, type, spectrum was recorded at $150 \mathrm{MHz}$. 
The relative configuration was established by a careful analysis of the ${ }^{1} \mathrm{H}-{ }^{1} \mathrm{H}$ coupling constants and the NOESY spectrum. The sequence of NOE correlations between protons H-15, H-6, H-12, H-10, H-9b and H-8 suggested that these protons were on the same side of the molecule (Figure 2). The relative configuration at C-10 was confirmed by the coupling constants of $\mathrm{H}-9 \mathrm{a}(11.9 \mathrm{~Hz})$ and $\mathrm{H}-11 \mathrm{a}(J=10.8 \mathrm{~Hz})$ with $\mathrm{H}-10$. These values suggested that the three protons were in an axial position. The large couplings $(\approx 10.4 \mathrm{~Hz})$ between $\mathrm{H}-7$ and its vicinal protons $\mathrm{H}-6, \mathrm{H}-8$ and $\mathrm{H}-12$ indicated that all these protons were axial, therefore suggesting a trans decaline skeleton. Finally, the strong NOE correlation between H-7 and H-21 further confirmed the configuration at C-15. Interestingly, carbon $\mathrm{C}-21$ was almost never detected in ${ }^{13} \mathrm{C}$ NMR spectra of compounds 1-13. Steric hindrance most likely decreased its relaxation rate. Compound 1 was named carneic acid C.

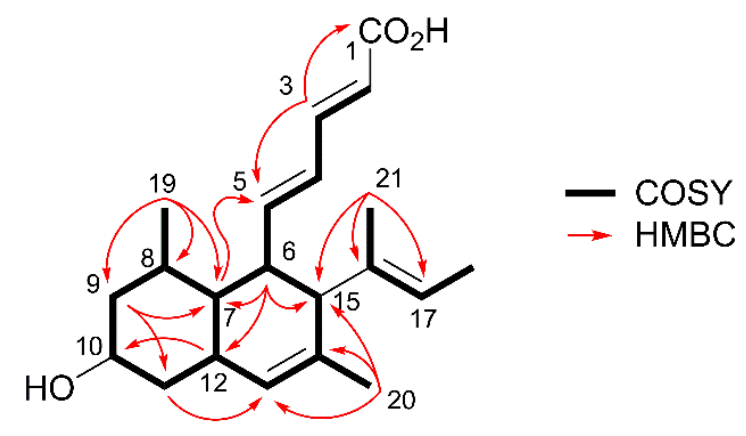

Figure 1. Key COSY (bold) and HMBC correlations of carneic acid C (1). 


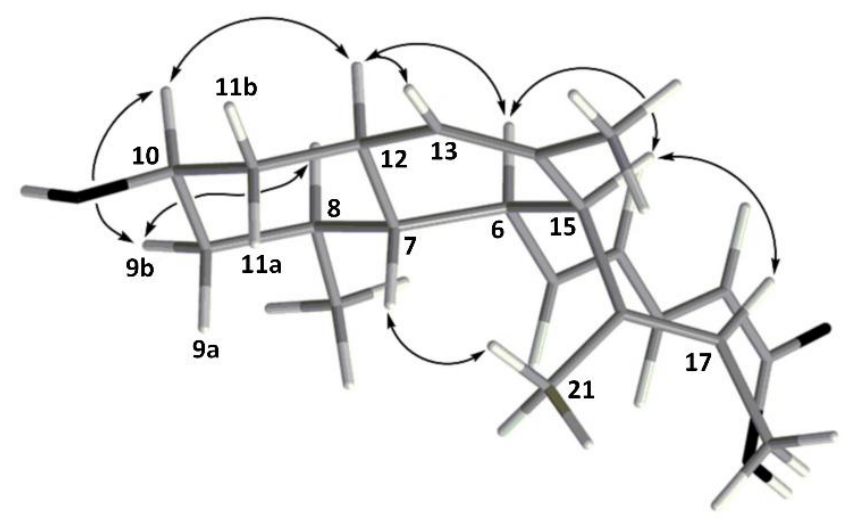

Figure 2. Key NOESY correlations of carneic acid C (1).

Compound $\mathbf{2}$ had the same molecular formula as $\mathbf{1}$, as evidenced by the protonated molecular ion detected by HRESIMS. The ${ }^{1} \mathrm{H}$ and ${ }^{13} \mathrm{C}$ NMR spectroscopic data (Tables 1 and 2) were almost identical to those of $\mathbf{1}$. Only slight differences were observed for the chemical shifts of C-10 and H-10 $\left(\delta_{\mathrm{C}} 69.8, \delta_{\mathrm{H}} 3.70\right.$ for 1 and $\delta_{\mathrm{C}} 66.8, \delta_{\mathrm{H}} 4.14$ for 2$)$. The HMBC and COSY spectra did not show any noticeable differences from those of $\mathbf{1}$, but the coupling pattern of proton H-10 was significantly different [brquint $(J=2.3 \mathrm{~Hz})$ in 2 compared to a brtt $(J=10.9$, 4. $4 \mathrm{~Hz}$ ) in 1]. In addition, NOE correlations between $\mathrm{H}-10$ and H-9a, H-9b, H-11a and H-11b further suggested an equatorial position of $\mathrm{H}-10$ in compound 2 , which was named carneic acid D.

$\mathrm{A}[\mathrm{M}+\mathrm{H}]^{+}$ion peak at $\mathrm{m} / \mathrm{z} 373.2384$ was detected in the HRESIMS spectrum of compound 3, which suggested a molecular formula of $\mathrm{C}_{23} \mathrm{H}_{32} \mathrm{O}_{4}$. The molecular formula indicated 8 degrees of unsaturation and an additional acetyl group compared to compounds $\mathbf{1}$ and 2. The ${ }^{1} \mathrm{H}$ and ${ }^{13} \mathrm{C}$ NMR spectroscopic data (Tables 1 and 2) were almost identical to those of $\mathbf{1}$ and 2, except for position 10 . The chemical shifts of $\mathrm{H}-10\left(\delta_{\mathrm{H}} 5.07\right)$ and $\mathrm{C}-10\left(\delta_{\mathrm{C}} 70.1\right)$ and the analysis of HMBC spectrum suggested that an acetate moiety was linked to C-10, with both Me- 
23 and $\mathrm{H}-10$ correlating with $\mathrm{C}-22$ at $\delta_{\mathrm{C}} 170.9$. ROESY correlations revealed that $\mathrm{H}-6, \mathrm{H}-8, \mathrm{H}-$ $11 \mathrm{~b}$ and $\mathrm{H}-12$ were on the same side of the molecule. The H-10 signal splitting pattern (brquint, $J=2.9 \mathrm{~Hz}$ ) and ROESY correlations between $\mathrm{H}-10$ and $\mathrm{H}-9 \mathrm{a}, \mathrm{H}-9 \mathrm{~b}, \mathrm{H}-11 \mathrm{a}$, and $\mathrm{H}-11 \mathrm{~b}$ revealed an equatorial position of $\mathrm{H}-10$. This compound was named carneic acid $\mathrm{E}$.

A $[\mathrm{M}+\mathrm{H}]^{+}$ion peak at $\mathrm{m} / z 329.2114$ was detected in the HRESIMS spectrum of compound 4 , which suggested a molecular formula of $\mathrm{C}_{21} \mathrm{H}_{28} \mathrm{O}_{3}$. The ${ }^{1} \mathrm{H}$ and ${ }^{13} \mathrm{C}$ NMR spectra (Tables 1 and 2) were almost identical to those of $\mathbf{1}$, except for $\mathrm{C}-10$, which turned out to be a carbonyl group $\left(\delta_{\mathrm{C}} 211.7\right)$. This compound was named carneic acid $\mathrm{F}$.

Compounds $\mathbf{5}$ and $\mathbf{6}$ had the same molecular formula as indicated by HRESIMS. Compound 5 showed an ion at $m / z, 329.2117\left[\mathrm{M}+\mathrm{H}-\mathrm{H}_{2} \mathrm{O}\right]^{+}$and compound $\mathbf{6}$ an ion at $\mathrm{m} / \mathrm{z}$ $329.2103\left[\mathrm{M}+\mathrm{H}-\mathrm{H}_{2} \mathrm{O}\right]^{+}$. Their molecular formula $\left(\mathrm{C}_{21} \mathrm{H}_{30} \mathrm{O}_{4}\right)$ and their ${ }^{13} \mathrm{C}$ and ${ }^{1} \mathrm{H}$ NMR spectra (Tables 1 and 2) suggested the same carbon skeleton as $\mathbf{1}$ and $\mathbf{2}$, but with an additional hydroxy group in C-18 $\left(\delta_{\mathrm{C}-18} 59.2, \delta_{\mathrm{H}-18} 4.21\right.$ for $\mathbf{5}$, and $\delta_{\mathrm{C}-18} 59.8, \delta_{\mathrm{H}-18} 4.14$ for $\left.\mathbf{6}\right)$. The position of the hydroxy group was confirmed by the HMBC correlations H-17/C-18 and H-21/C-18. The two compounds differed by their relative configuration of C-10, H-10 being axial in 5 and equatorial in 6. These compounds were named carneic acid G (5) and $\mathrm{H}(\mathbf{6})$.

Compound $\mathbf{7}$ had the same molecular formula as $\mathbf{5}$ and $\mathbf{6}$. Its HRESIMS indicated a protonated and dehydrated molecule at $m / z 329.2124\left[\mathrm{M}+\mathrm{H}-\mathrm{H}_{2} \mathrm{O}\right]{ }^{+}$. The ${ }^{1} \mathrm{H}$ and ${ }^{13} \mathrm{C}$ NMR spectroscopic data (Tables 1 and 2$)$ were almost identical to those of $\mathbf{5}$ and $\mathbf{6}$, except for C-9 $\left(\delta_{\mathrm{C}}\right.$ $\left.76.4, \delta_{\mathrm{H}} 3.17\right)$ and $\mathrm{C}-10\left(\delta_{\mathrm{C}} 35.4, \delta_{\mathrm{H}} 1.40,2.04\right)$. Chemical shifts suggested that 7 was hydroxylated at C-9 rather than at C-10. The relative configuration was determined by analysis of the ROESY spectrum. Correlations between H-7 and H-9 revealed that these protons were on 
the same side of the molecule, and correlations between $\mathrm{H}-6, \mathrm{H}-12$, and $\mathrm{H}-15$ indicated that these protons were on the other side of the molecule. The large $\mathrm{H}-8-\mathrm{H}-9$ coupling also confirmed the equatorial orientation of the hydroxy group in C-9. This compound was named carneic acid I.

Compound $\mathbf{8}$ had the molecular formula $\mathrm{C}_{21} \mathrm{H}_{30} \mathrm{O}_{3}$, as evidenced by the protonated, dehydrated ion at $m / z$ 313.2168 $\left[\mathrm{M}+\mathrm{H}-\mathrm{H}_{2} \mathrm{O}\right]^{+}$detected in HRESIMS. Comparison of the ${ }^{1} \mathrm{H}$ and ${ }^{13} \mathrm{C}$ NMR spectroscopic data with that of 7 (Tables 1-3) revealed that 8 was not hydroxylated in C-9. The left cyclohexane was fully aliphatic, and the compound was hydroxylated at C-18. This compound was named carneic acid J. 
Table 3. ${ }^{1} \mathrm{H}$ NMR Spectroscopic Data $\left(\mathrm{CDCl}_{3}\right)$ for Compounds 8-13.

\begin{tabular}{|c|c|c|c|c|c|c|}
\hline Position & 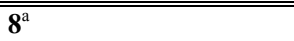 & $9^{\mathrm{a}}$ & $1 \mathbf{1 0}^{\mathrm{a}}$ & $11^{\mathrm{a}}$ & $12^{\mathrm{a}}$ & $13^{\mathrm{a}}$ \\
\hline 2 & $5.78 \mathrm{~d}(15.1)$ & $5.81 \mathrm{~d}(15.4)$ & 5.83 brd (14.3) & $5.78 \mathrm{~d}(15.2)$ & $5.80 \mathrm{~d}(15.3)$ & $5.81 \mathrm{~d}(15.3)$ \\
\hline 3 & 7.33 ddd $(15.1,7.0,3.2)$ & $7.29 \mathrm{dd}(15.4,11.1)$ & $7.30 \mathrm{~m}$ & 7.28 brdd $(15.2,10.4)$ & $7.34 \mathrm{~m}$ & 7.34 brdd $(15.3,9.8)$ \\
\hline 4 & $6.11 \mathrm{~m}$ & $6.17 \mathrm{dd}(14.7,11.1)$ & $6.19 \mathrm{dd}(14.9,11.1)$ & $6.09 \mathrm{dd}(15.1,10.2)$ & $6.10 \mathrm{~m}$ & $6.133 \mathrm{~m}$ \\
\hline 5 & $6.12 \mathrm{~m}$ & $6.03 \mathrm{dd}(14.7,11.0)$ & 5.99 dd $(14.9,10.9)$ & $6.02 \mathrm{dd}(15.1,10.4)$ & $6.12 \mathrm{~m}$ & $6.126 \mathrm{~m}$ \\
\hline 6 & $2.46 \mathrm{~m}$ & $2.48 \mathrm{~m}$ & $2.51 \mathrm{td}(10.9,6.3)$ & $2.41 \operatorname{brtd}(10.7,6.0)$ & $2.52 \mathrm{~m}$ & $2.54 \mathrm{~m}$ \\
\hline 7 & $1.20 \mathrm{~m}$ & 1.43 brq $(10.0)$ & 1.40 brq $(10.0)$ & 1.15 brq $(10.3)$ & $1.30 \mathrm{q}(10.2)$ & $1.40 \mathrm{~m}$ \\
\hline 8 & $1.51 \mathrm{~m}$ & 1.79 brhept (7.3) & 1.80 brhept (7.2) & $1.34 \mathrm{~m}$ & $1.16 \mathrm{~m}$ & $1.40 \mathrm{~m}$ \\
\hline 9 & $\begin{array}{l}\text { a: } 1.63 \mathrm{~m} \\
\text { b: } 1.04 \mathrm{~m}\end{array}$ & $\begin{array}{l}\text { a: } 2.05 \mathrm{~m} \\
\text { b: } 2.56 \mathrm{dd}(14.6,6.8)\end{array}$ & $\begin{array}{l}\text { a: } 2.05 \mathrm{~m} \\
\text { b: } 2.57 \mathrm{dd}(14.6,6.6)\end{array}$ & $\begin{array}{l}\text { a: } 1.07 \text { brq (12.0) } \\
\text { b: } 1.90 \text { brd (12.0) }\end{array}$ & 3.16 ddd $(11.0,9.4,4.6)$ & 4.46 brddd $(11.6,9.3,4.8)$ \\
\hline 10 & $\begin{array}{l}\text { a: } 1.35 \mathrm{~m} \\
\text { b: } 1.68 \mathrm{~m}\end{array}$ & & & 3.68 brtt $(10.8,4.4)$ & $\begin{array}{l}\text { a: } 1.40 \mathrm{brqd}(12.2,3.9) \\
\text { b: } 2.04 \mathrm{~m}\end{array}$ & $\begin{array}{l}\text { a: } 1.41 \mathrm{~m} \\
\mathrm{~b}: 2.06 \mathrm{~m}\end{array}$ \\
\hline 11 & $\begin{array}{l}\text { a: } 1.69 \mathrm{~m} \\
\text { b: } 1.06 \mathrm{~m}\end{array}$ & $\begin{array}{l}\text { a: } 2.06 \mathrm{~m} \\
\text { b: } 2.48 \mathrm{~m}\end{array}$ & $\begin{array}{l}\text { a: } 2.05 \mathrm{~m} \\
\text { b: } 2.48 \mathrm{dd}(16.2,3.7)\end{array}$ & $\begin{array}{l}\text { a: } 1.10 \text { brq (12.0) } \\
\text { b: } 2.00 \text { brd (12.0) }\end{array}$ & $\begin{array}{l}\text { a: } 1.16 \mathrm{~m} \\
\text { b: } 1.76 \mathrm{~m}\end{array}$ & $\begin{array}{l}\text { a: } 1.24 \text { brqd }(13.0,3.3) \\
\text { b: } 1.76 \text { brdq }(13.0,3.4)\end{array}$ \\
\hline 12 & $1.71 \mathrm{~m}$ & $2.34 \mathrm{brt}(11.0)$ & 2.35 brt (12.0) & 1.78 brt (10.9) & $1.77 \mathrm{~m}$ & $1.81 \mathrm{~m}$ \\
\hline 13 & 5.28 brs & 5.29 brs & $5.31 \mathrm{~s}$ & $5.27 \mathrm{~s}$ & $5.318 \mathrm{~s}$ & $5.31 \mathrm{brs}$ \\
\hline 15 & 2.52 brd (5.8) & 2.63 brd (6.1) & 2.66 brd (5.7) & 2.55 brd (6.0) & 2.57 brd (5.7) & 2.57 brd (5.8) \\
\hline 17 & 5.39 brt (6.5) & 5.43 brt (6.2) & 5.34 brt (6.6) & 5.29 brt (6.8) & 5.316 tq $(6.9,1.1)$ & 5.40 brt (6.5) \\
\hline 18 & $\begin{array}{l}\text { a: } 4.18 \mathrm{dd}(12.7,6.4) \\
\text { b: } 4.22 \mathrm{dd}(12.7,6.7)\end{array}$ & 4.21 brd (6.2) & $4.62 \mathrm{~d}(6.7)$ & 4.59 brd (6.8) & 4.61 brd (6.9) & $\begin{array}{l}\text { a: } 4.24 \mathrm{dd}(12.7,6.5) \\
\text { b: } 4.20 \mathrm{dd}(12.7,6.5)\end{array}$ \\
\hline 19 & $0.83 \mathrm{~d}(5.5)$ & $0.90 \mathrm{~d}(6.4)$ & $0.92 \mathrm{~d}(6.6)$ & $0.89 \mathrm{~d}(6.3)$ & $1.03 \mathrm{~d}(6.2)$ & $0.88 \mathrm{~d}(5.6)$ \\
\hline 20 & $1.50 \mathrm{~s}$ & $1.55 \mathrm{~s}$ & $1.55 \mathrm{~s}$ & $1.49 \mathrm{~s}$ & 1.51 brs & $1.53 \mathrm{~s}$ \\
\hline 21 & $1.63 \mathrm{~s}$ & $1.66 \mathrm{~s}$ & $1.71 \mathrm{~s}$ & $1.66 \mathrm{~s}$ & $1.69 \mathrm{~s}$ & $1.65 \mathrm{~s}$ \\
\hline 23 & & & $2.06 \mathrm{~s}$ & $2.04 \mathrm{~s}$ & $2.06 \mathrm{~s}$ & $2.03 \mathrm{~s}$ \\
\hline
\end{tabular}


Compound 9 had the molecular formula $\mathrm{C}_{21} \mathrm{H}_{28} \mathrm{O}_{4}$, as evidenced by the $\left[\mathrm{M}+\mathrm{H}-\mathrm{H}_{2} \mathrm{O}\right]^{+}$ion at $m / z 327.1955$ detected by HRESIMS. The ${ }^{1} \mathrm{H}$ and ${ }^{13} \mathrm{C}$ NMR data were almost identical to those of 4 (Tables 2 and 3). The only significant difference was the chemical shifts in position 18 $\left(\delta_{\mathrm{C}} 13.6, \delta_{\mathrm{H}} 1.64\right.$ for 4 and $\delta_{\mathrm{C}} 59.0, \delta_{\mathrm{H}} 4.21$ for 9 ). The molecular formula, ${ }^{13} \mathrm{C}$ NMR and ${ }^{1} \mathrm{H}$ NMR spectra suggested the same carbon skeleton as for $\mathbf{4}$, with an additional hydroxy group in C-18. Compound 9 was named carneic acid $\mathrm{K}$.

The HRESIMS of compound $\mathbf{1 0}$ suggested a molecular formula of $\mathrm{C}_{23} \mathrm{H}_{30} \mathrm{O}_{5}$. The ${ }^{1} \mathrm{H}$ and ${ }^{13} \mathrm{C}$ NMR spectroscopic data were almost identical to those of 9 (Tables 2 and 3), in which the hydroxy group in C-18 had been acetylated $\left[\delta_{\mathrm{C}} 61.5, \delta_{\mathrm{H}} 4.62(\mathrm{~d}, J=6.7 \mathrm{~Hz})\right]$. This compound was named carneic acid L.

Compound 11 has the molecular formula $\mathrm{C}_{23} \mathrm{H}_{32} \mathrm{O}_{5}$, as evidenced by the $\left[\mathrm{M}+\mathrm{H}-\mathrm{H}_{2} \mathrm{O}\right]^{+}$ ion at $m / z 371.2224$ detected in HRESIMS. The ${ }^{1} \mathrm{H}$ and ${ }^{13} \mathrm{C}$ NMR data compared to those of $\mathbf{1 0}$ (Tables 2 and 3 ) revealed the presence of a hydroxy group in $\mathrm{C}-10\left(\delta_{\mathrm{C}} 69.8, \delta_{\mathrm{H}} 3.68\right)$. The latter was equatorial (and proton $\mathrm{H}-10$ axial), as evidenced by ROE correlations between $\mathrm{H}-10$ axial and both H-8 and H-12. This compound was named carneic acid M.

Compounds $\mathbf{1 2}$ and $\mathbf{1 3}$ both had molecular formulas identical to that of compound 11, i.e., $\mathrm{C}_{23} \mathrm{H}_{32} \mathrm{O}_{5}$, as evidenced by the $\left[\mathrm{M}+\mathrm{H}-\mathrm{H}_{2} \mathrm{O}\right]^{+}$ions at $\mathrm{m} / \mathrm{z} 371.2227$ for $\mathbf{1 2}$ and 371.2212 for 13. The ${ }^{1} \mathrm{H}$ and ${ }^{13} \mathrm{C}$ NMR spectroscopic data were almost identical to those of $\mathbf{1 1}$ (Tables 2 and 3). The NMR data showed that $\mathbf{1 2}$ and $\mathbf{1 3}$ were both hydroxylated in $\mathrm{C}-9\left(\delta_{\mathrm{C}} 76.1, \delta_{\mathrm{H}} 3.16\right.$ for $\mathbf{1 2}$ and $\delta_{\mathrm{C}} 78.1, \delta_{\mathrm{H}} 4.46$ for $\mathbf{1 3}$ ) rather than in C-10 for 11. The ROESY spectra allowed us to distinguish the relative configurations of $\mathbf{1 2}$ and $\mathbf{1 3}$. In 12, ROE correlations between H-9 and H7 and between $\mathrm{H}-9$ and $\mathrm{H}-11$ a suggested that these protons were on the same side of the 
molecule. In 13, H-9 correlated with $\mathrm{H}-10 \mathrm{a}$ and $\mathrm{H}-10 \mathrm{~b}$, which is typical of an equatorial position. These compounds were named carneic acids $\mathrm{N}(\mathbf{1 2})$ and $\mathrm{O}(\mathbf{1 3})$.

To determine their viral inhibition potential, compounds 1-13 were evaluated on a DENV RNA-dependent RNA polymerase assay (Table 4). The $\mathrm{IC}_{50}$ values of the most active compounds (> $75 \%$ inhibition at $50 \mu \mathrm{g} / \mathrm{mL}$ ) were calculated. These compounds were also evaluated on Zika-NS5 (Table 4).

Table 4. Antiviral Activity and Cytotoxicity of Compounds 1-13.

\begin{tabular}{|c|c|c|c|c|c|c|c|c|}
\hline \multirow[t]{2}{*}{ Carneic acid } & \multicolumn{3}{|c|}{$\begin{array}{l}\text { DENV RdRp } \\
(\% \text { of inh. })^{\mathrm{a}}\end{array}$} & \multirow{2}{*}{$\begin{array}{l}\text { DENV RdRp } \\
\mathrm{IC}_{50}(\mu \mathrm{M})^{\mathrm{b}}\end{array}$} & \multicolumn{3}{|c|}{$\begin{array}{l}\text { Zika-NS5 } \\
(\% \text { of inh. })^{a}\end{array}$} & \multirow{2}{*}{$\begin{array}{l}\text { MRC-5 cell prolif. } \\
(\% \text { of living cells })^{\mathrm{c}} \\
10\end{array}$} \\
\hline & 50 & 10 & 1 & & 50 & 10 & 1 & \\
\hline C (1) & 85.0 & 46.0 & 6.4 & $19.0 \pm 2.4$ & 50.9 & 27.6 & 4.9 & $99.0 \pm 4.0$ \\
\hline D (2) & 78.1 & 59.4 & 15.3 & $19.0 \pm 2.4$ & 40.9 & 23.3 & 9.6 & $97.0 \pm 3.0$ \\
\hline E (3) & 88.9 & 62.3 & 2.8 & $15.5 \pm 3.2$ & 47.7 & 21.5 & 1.2 & $91.9 \pm 3.9$ \\
\hline F (4) & 85.1 & 65.6 & 7.9 & $11.8 \pm 0.9$ & 49.9 & 24.4 & 6.3 & $96.9 \pm 4.6$ \\
\hline$G(5)$ & 43.9 & 28.7 & 6.5 & - & 18.4 & 5.5 & 8.5 & $85.8 \pm 3.1$ \\
\hline $\mathrm{H}(\mathbf{6})$ & 42.8 & 49.0 & 2.0 & - & 15.0 & 6.0 & 15.2 & $79.3 \pm 2.9$ \\
\hline I (7) & 42.0 & 29.7 & 0 & - & 33.7 & 8.0 & 4.8 & $98.1 \pm 2.6$ \\
\hline $\mathrm{J}(\mathbf{8})$ & 75.5 & 51.2 & 13.2 & $37.5 \pm 3.9$ & 38.3 & 21.0 & 0 & $100.0 \pm 2.3$ \\
\hline K (9) & 36.7 & 23.8 & 0 & - & 25.5 & 0 & 0 & $100.0 \pm 3.6$ \\
\hline L (10) & 64.6 & 36.4 & 0 & - & 25.4 & 19.3 & 13.8 & $98.8 \pm 5.8$ \\
\hline M (11) & 52.3 & 28.9 & 4.7 & - & 32.0 & 3.3 & 0 & $98.5 \pm 0.7$ \\
\hline $\mathrm{N}(\mathbf{1 2})$ & 48.7 & 40.2 & 26.0 & - & 39.6 & 18.1 & 5.4 & $93.5 \pm 7.7$ \\
\hline $\mathrm{O}(\mathbf{1 3})$ & 85.4 & 61.0 & 10.5 & $13.6 \pm 1.5$ & 56.3 & 20.7 & 3.0 & $95.6 \pm 3.7$ \\
\hline
\end{tabular}

a $\%$ of inhibition at 50, 10 and $1 \mu \mathrm{g} / \mathrm{mL}$. Control: $3^{\text {' }}$-dATP at $10 \mu \mathrm{M}(96.1 \% \pm 0.5)$. ${ }^{\text {b }}$ IC $_{50}$ values are mean values \pm SD from three replicates. ${ }^{c} \%$ of living cells at $10 \mu \mathrm{g} / \mathrm{mL}$

None of the tested compounds showed cytotoxicity. The Zika bioassay did not reveal significant inhibition of NS5. Only carneic acids C (1), D (2), E (3), F (4) and O (13) exhibited significant DENV-2 polymerase inhibition activity, with $\mathrm{IC}_{50}$ values in the $10.0-20.0 \mu \mathrm{M}$ range, compounds 4 and 13 being the most active of the series. All other compounds were considered inactive. 
Some very interesting observations can be summarized from the DENV-2 polymerase bioassay results. In the carneic acid series (1-13), it is suggested that the 1-methypropenyl unit in position C-15 plays an important role in the DENV-2 enzyme inhibiting activity. When this subunit is oxidized at C-18, the compounds are less active ( $\mathbf{1}$ vs $\mathbf{5}$ and 11, 2 vs $\mathbf{6}, \mathbf{4}$ vs 9 and 10). The anti-DENV2 enzyme activities of compounds 1-4 are almost identical, indicating that the oxidation pattern on the left ring (compounds 1-4) does not influence the biological activity. Finally, compounds $\mathbf{5 - 1 3}$ all possess a 3-hydroxy-1-methylpropenyl unit or a 3-acetoxy-1methylpropenyl unit at C-15 but are differently substituted on the decaline left ring. In this series, since only compound $\mathbf{1 3}$ showed significant inhibitory activity on DENV2 polymerase, it can be inferred that a $\beta-\mathrm{OH}$ group in $\mathrm{C}-9$ can promote enzyme inhibitory activity. Unfortunately, it was not possible at this stage to isolate a carneic acid bearing both a $\beta$-OH group in C-9 and a 1methypropenyl side chain in C-15.

The previous study on carneic acids from Hypoxylon carneum described that carneic acids A and B showed weak antibacterial and moderate antifungal activities. ${ }^{12}$ The closest structural analogue of the carneic acids is phomopsidin, an antibiotic cis-decaline isolated from a marine Phomopsis sp. that was shown to inhibit microtubule assembly. ${ }^{14,15}$ Two other structurally related compounds have been isolated from Fusarium (Fusarielins) ${ }^{16}$ and Phoma sp. (MK8383) ${ }^{15}$ Our work is the first to demonstrate antiviral activity within this class of compounds.

\section{- EXPERIMENTAL SECTION}

General Experimental Procedures. Optical rotation was measured in methanol using an Anton Paar MCP 300 polarimeter in a 100-mm-long, 350- $\mu \mathrm{L}$ cell. NMR spectra were recorded in 
$\mathrm{CDCl}_{3}, \mathrm{MeOH}$ or Pyridine on a Bruker $600 \mathrm{MHz}$ or $500 \mathrm{MHz}$ spectrometer equipped with a 1$\mathrm{mm}$ inverse detection probe.

UHPLC was performed with a Waters Acquity UPLC system equipped with a Waters Acquity PDA detector. The wavelength range was between 210 to $410 \mathrm{~nm}$. Separation was achieved on a Kromasil BEH $\mathrm{C}_{18}$ column $(1.7 \mu \mathrm{m}, 2.1 \mathrm{~mm} \times 50 \mathrm{~mm})$ at a flow rate of 0.6 $\mathrm{mL} / \mathrm{min}$. Elution was conducted with a $\mathrm{H}_{2} \mathrm{O}$-acetonitrile $(\mathrm{ACN})$ gradient as follows: $95: 5$ to 0:100 in 5.5 min. The UPLC system was coupled to a Waters LCT Premier XE mass spectrometer equipped with an electrospray ionization source. The ionization was carried out in positive mode in the $80-1500 \mathrm{~m} / \mathrm{z}$ range. The ACN used for HPLC and UHPLC chromatography was LC-MS grade (Fisher Scientific, Illkirch, FR). Deionized water was obtained from a Millipore (Bedford, USA) Milli-Q purification system. For all HPLC and UHPLC analyses, 0.1 $\%$ formic acid was added to $\mathrm{ACN}$ and water.

Flash chromatography was performed on a Grace Reveleris system with dual UV and ELSD detection equipped with a Reveleris $40 \mathrm{~g}$ silica $\mathrm{C}_{18}$ cartridge. For purification of fraction 6, normal flash chromatography was used (Puriflash $12 \mathrm{~g}$ silica cartridge). Effluents were monitored at 254 and $280 \mathrm{~nm} . \mathrm{H}_{2} \mathrm{O}, \mathrm{ACN}$, dichloromethane (DCM) and tetrahydrofuran (THF) were used for Flash chromatography. Thin-layer chromatography (TLC) was conducted on $60 \mathrm{~A}$ F254 Merck plates, visualized using UV detection, and sprayed with a $1 \%$ solution of vanillin in concentrated sulfuric acid. Thermo Kromasil analytical and preparative $\mathrm{C}_{18}$ columns $(250 \times 4.6$ $\mathrm{mm}$ and $250 \times 21.2 \mathrm{~mm}, 5 \mu \mathrm{m}$ ) were used for HPLC separations using a Waters autopurification system equipped with a sample manager (Waters 2767), a column fluidics organizer, a binary pump (Waters 2525), a UV-vis diode array detector (190-600 nm, Waters 2996), and a Polymer Laboratory PL-ELS 1000 ELSD detector. The flow rates were $1 \mathrm{~mL} / \mathrm{min}$ for analytical HPLC 
analysis and $21 \mathrm{~mL} / \mathrm{min}$ for preparative HPLC analysis, using a gradient of $\mathrm{H}_{2} \mathrm{O}$ mixed with an increasing proportion of ACN. Both solvents were modified with $0.1 \%$ formic acid.

Plant Material. The leaves and bark of D. carbonaria were collected in October 2013 in French Guiana (Saint Elie). The species was identified by Dr. V. Eparvier. A voucher specimen was deposited in the Cayenne Herbarium (CAYVE18).

Isolation, Identification and Extraction of Endophytes. The general procedures adopted for isolation and identification of the endophytic microorganisms followed the methodology described by Casella et al. ${ }^{6}$ Thirty-eight fungal strains were isolated from $D$. carbonaria leaves and bark. All strains were sequenced externally by BACTUP-France for identification. The fungal rDNA sequences obtained were aligned with DNA sequences from GenBank, NCBI (http://www.ncbi.nlm.nih.gov/genbank, consulted in July 2015) for identification. The sequence of the endophyte Phomopsis sp. SNB-LAP1-7-32 was deposited in GenBank with the accession number KU977311.

\section{Large-scale Cultivation and Extraction of SNB-LAP1-7-32. Phomopsis sp. was} cultivated on solid PDA medium at $26^{\circ} \mathrm{C}$ for $15 \mathrm{~d}$ on 482 14-cm-diameter Petri dishes (total $36.9 \mathrm{~m}^{2}$ ). The contents of the Petri dishes were cut into small pieces, transferred into a large container, and macerated with EtOAc 3 times for $24 \mathrm{~h}$. After each maceration, the organic solvent was collected by filtration. The combined organic phases were washed with water in a separating funnel, yielding $7.3 \mathrm{~g}$ of extract after evaporation $\left(0.31 \mathrm{~g} / \mathrm{m}^{2}\right)$. To eliminate fatty acids, the extract was diluted in heptane- $\mathrm{H}_{2} \mathrm{O}-\mathrm{MeOH}(2: 1: 1)$, and the $\mathrm{H}_{2} \mathrm{O}-\mathrm{MeOH}$ phase was evaporated to dryness under reduced pressure, yielding $3.4 \mathrm{~g}$ of extract. 
Isolation of Compounds from Phomopsis sp. The extract (3.4 g) was purified by flash chromatography with a gradient of $\mathrm{H}_{2} \mathrm{O}-\mathrm{ACN}(95: 5-80: 20$ - 50:50 - 20:80 - 0:100), followed by ACN-THF (50:50, and 100:0) at $40 \mathrm{~mL} / \mathrm{min}$. Eight fractions were gathered based on their TLC profiles and were separated with preparative HPLC (flow rate $21 \mathrm{~mL} / \mathrm{min}$ ).

Three carneic acids were isolated from fraction V (160.2 mg) by prep-HPLC using a gradient of $\mathrm{H}_{2} \mathrm{O}-\mathrm{ACN}$ (70:30 to 0:100 in $70 \mathrm{~min}$ ): carneic acid $\mathrm{G}(\mathbf{5})\left(2.4 \mathrm{mg}, t_{\mathrm{R}}=11.9 \mathrm{~min}\right)$, carneic acid $\mathrm{H}(\mathbf{6})\left(1.2 \mathrm{mg}, t_{\mathrm{R}}=12.1 \mathrm{~min}\right)$ and carneic acid $\mathrm{I}(7)\left(3.7 \mathrm{mg}, t_{\mathrm{R}}=14.8 \mathrm{~min}\right)$. Fraction VI (139.6 mg) was separated by normal flash chromatography into 8 subfractions. Subfraction 4 (100.6 mg) was purified by prep-HPLC using a gradient of $\mathrm{H}_{2} \mathrm{O}-\mathrm{ACN}$ (50:50 to 0:100 in 30 min). Two compounds were isolated: carneic acid $\mathrm{L}(\mathbf{1 0})\left(0.9 \mathrm{mg}, t_{\mathrm{R}}=9.2 \mathrm{~min}\right)$ and carneic acid F (4) $\left(1.5 \mathrm{mg}, t_{\mathrm{R}}=13.3 \mathrm{~min}\right)$. Subfraction $5(100.6 \mathrm{mg})$, purified by prep-HPLC eluted with $\mathrm{H}_{2} \mathrm{O}-$ ACN 45:55, yielded carneic acids $\mathrm{K}(\mathbf{9})\left(0.9 \mathrm{mg}, t_{\mathrm{R}}=4.7 \mathrm{~min}\right), \mathrm{M}(\mathbf{1 1})\left(0.7 \mathrm{mg}, t_{\mathrm{R}}=6.4 \mathrm{~min}\right), \mathrm{N}$ (12) $\left(1.6 \mathrm{mg}, t_{\mathrm{R}}=10.4 \mathrm{~min}\right), \mathrm{C}(\mathbf{1})\left(2.6 \mathrm{mg}, t_{\mathrm{R}}=11.1 \mathrm{~min}\right), \mathrm{O}(\mathbf{1 3})\left(1.3 \mathrm{mg}, t_{\mathrm{R}}=12.5 \mathrm{~min}\right), \mathrm{D}(\mathbf{2})$ $\left(1.6 \mathrm{mg}, t_{\mathrm{R}}=15.4 \mathrm{~min}\right)$ and $\mathrm{J}(\mathbf{8})\left(0.5 \mathrm{mg}, t_{\mathrm{R}}=15.7 \mathrm{~min}\right)$. Fraction VII (139.6 mg), purified by prep-HPLC with a gradient of $\mathrm{H}_{2} \mathrm{O}-\mathrm{ACN}$ (40:60 to 0:100 in $40 \mathrm{~min}$ ), allowed isolation of carneic acid $\mathrm{E}(\mathbf{3})\left(0.3 \mathrm{mg}, t_{\mathrm{R}}=7.3 \mathrm{~min}\right)$.

Carneic acid C (1): $[\alpha]^{25}-595.0\left(\right.$ c 0.1, $\left.\mathrm{CDCl}_{3}\right)$; UV (MeOH) $\lambda_{\max }(\log \varepsilon) 201(5.18) \mathrm{nm} ; \mathrm{IR}$ $\left(\mathrm{CDCl}_{3}\right) \gamma_{\max } 3369.99,1689.63,1635.63,1250.33,1007.75 \mathrm{~cm}^{-1} ;{ }^{1} \mathrm{H}$ and ${ }^{13} \mathrm{C}$ NMR data in Tables 1 and 2; HRMS $m / z 331.2289[\mathrm{M}+\mathrm{H}]^{+}$(calcd. for $\mathrm{C}_{21} \mathrm{H}_{31} \mathrm{O}_{3}{ }^{+}, 331.2268$ ).

Carneic acid D (2): $[\alpha]^{25}-279.0\left(\right.$ c $\left.0.1, \mathrm{CDCl}_{3}\right)$; UV (MeOH) $\lambda_{\max }(\log \varepsilon) 201$ (4.71), 261 (4.37) $\mathrm{nm} ; \mathrm{IR}\left(\mathrm{CDCl}_{3}\right) \gamma_{\max } 3384.94,1690.63,1636.20,1253.29,1009.52 \mathrm{~cm}^{-1} ;{ }^{1} \mathrm{H}$ and ${ }^{13} \mathrm{C}$ NMR data in Tables 1 and 2; HRMS $m / z$ 331.2273 $[\mathrm{M}+\mathrm{H}]^{+}$(calcd. for $\mathrm{C}_{21} \mathrm{H}_{31} \mathrm{O}_{3}{ }^{+}, 331.2268$ ). 
Carneic acid $E$ (3): $[\alpha]^{25}{ }_{\mathrm{D}}-46.0\left(c 0.05, \mathrm{CDCl}_{3}\right) ;{ }^{1} \mathrm{H}$ and ${ }^{13} \mathrm{C}$ NMR data in Tables 1 and 2; HRMS $m / z 373.2384[\mathrm{M}+\mathrm{H}]^{+}$(calcd. for $\mathrm{C}_{23} \mathrm{H}_{33} \mathrm{O}_{4}{ }^{+}, 373.2373$ ).

Carneic acid $F(4):[\alpha]^{25}-147.0\left(c\right.$ 0.1, $\left.\mathrm{CDCl}_{3}\right) ;{ }^{1} \mathrm{H}$ and ${ }^{13} \mathrm{C}$ NMR data in Tables 1 and 2; HRMS $m / z 329.2114[\mathrm{M}+\mathrm{H}]^{+}$(calcd. for $\mathrm{C}_{21} \mathrm{H}_{29} \mathrm{O}_{3}{ }^{+}, 329.2111$ ).

Carneic acid $G(5)$ : $[\alpha]^{25}{ }_{\mathrm{D}}-5.0\left(c 0.1, \mathrm{CDCl}_{3}\right) ;{ }^{1} \mathrm{H}$ and ${ }^{13} \mathrm{C}$ NMR data in Tables 1 and 2; HRMS $m / z 329.2117\left[\mathrm{M}+\mathrm{H}-\mathrm{H}_{2} \mathrm{O}\right]^{+}$(calcd. for $\mathrm{C}_{21} \mathrm{H}_{29} \mathrm{O}_{3}{ }^{+}, 329.2111$ ).

Carneic acid $H(\mathbf{6}):[\alpha]^{25}{ }_{\mathrm{D}}-12.0\left(c 0.1, \mathrm{CDCl}_{3}\right) ;{ }^{1} \mathrm{H}$ and ${ }^{13} \mathrm{C}$ NMR data in Tables 1 and 2; HRMS $m / z 329.2103\left[\mathrm{M}+\mathrm{H}-\mathrm{H}_{2} \mathrm{O}\right]^{+}$(calcd. for $\mathrm{C}_{21} \mathrm{H}_{29} \mathrm{O}_{3}{ }^{+}, 329.2111$ ).

Carneic acid I (7): $[\alpha]^{25}{ }_{\mathrm{D}}-122.0\left(\right.$ c 0.1, $\left.\mathrm{CDCl}_{3}\right)$; UV (MeOH) $\lambda_{\max }(\log \varepsilon) 201$ (4.51), 260 (4.04) $\mathrm{nm}$; IR $\left(\mathrm{CDCl}_{3}\right) \gamma_{\max } 3371.65,1685.80,1636.75,1258.04,1012.79 \mathrm{~cm}^{-1} ;{ }^{1} \mathrm{H}$ and ${ }^{13} \mathrm{C}$ NMR data in Tables 1 and 2; HRMS $m / z 329.2124\left[\mathrm{M}+\mathrm{H}-\mathrm{H}_{2} \mathrm{O}\right]^{+}$(calcd. for $\mathrm{C}_{21} \mathrm{H}_{29} \mathrm{O}_{3}{ }^{+}, 329.2111$ ).

Carneic acid $J(8)$ : $[\alpha]^{25}{ }_{\mathrm{D}}-38.0\left(c 0.1, \mathrm{CDCl}_{3}\right) ;{ }^{1} \mathrm{H}$ and ${ }^{13} \mathrm{C}$ NMR data in Tables 3 and 2; HRMS $m / z 313.2168\left[\mathrm{M}+\mathrm{H}-\mathrm{H}_{2} \mathrm{O}\right]^{+}$(calcd. for $\mathrm{C}_{21} \mathrm{H}_{29} \mathrm{O}_{2}{ }^{+}, 313.2162$ ).

Carneic acid $K$ (9): $[\alpha]^{25}{ }_{D}-206.0\left(\right.$ c 0.1, $\left.\mathrm{CDCl}_{3}\right)$; IR $\left(\mathrm{CDCl}_{3}\right) \gamma_{\max }$ 1702.74, 1640.21, 1393.95, 1260.53, 1066.15 $\mathrm{cm}^{-1} ;{ }^{1} \mathrm{H}$ and ${ }^{13} \mathrm{C}$ NMR data in Tables 3 and 2; HRMS $m / z 327.1955[\mathrm{M}+\mathrm{H}-$ $\left.\mathrm{H}_{2} \mathrm{O}\right]^{+}$(calcd. for $\mathrm{C}_{21} \mathrm{H}_{27} \mathrm{O}_{3}{ }^{+}, 327.1955$ ).

Carneic acid L (10): $[\alpha]^{25}{ }_{\mathrm{D}}-57.0\left(\right.$ c 0.05, $\left.\mathrm{CDCl}_{3}\right) ; \mathrm{IR}\left(\mathrm{CDCl}_{3}\right) \gamma_{\max } 1740.41,1226.71 \mathrm{~cm}^{-1} ;{ }^{1} \mathrm{H}$ and ${ }^{13} \mathrm{C}$ NMR data in Tables 3 and 2; HRMS m/z $409.1991[\mathrm{M}+\mathrm{Na}]^{+}$(calcd. for $\mathrm{C}_{23} \mathrm{H}_{30} \mathrm{O}_{5} \mathrm{Na}^{+}$, 409.1985). 
Carneic acid $M(11):[\alpha]^{25}-86.0\left(\right.$ c $\left.0.1, \mathrm{CDCl}_{3}\right) ;{ }^{1} \mathrm{H}$ and ${ }^{13} \mathrm{C}$ NMR data in Tables 3 and 2; HRMS m/z $371.2224\left[\mathrm{M}+\mathrm{H}-\mathrm{H}_{2} \mathrm{O}\right]^{+}$(calcd. for $\mathrm{C}_{23} \mathrm{H}_{31} \mathrm{O}_{4}{ }^{+}, 371.2217$ ).

Carneic acid $N$ (12): $[\alpha]^{25}{ }_{\mathrm{D}}-81.0\left(\right.$ c $\left.0.1, \mathrm{CDCl}_{3}\right) ;{ }^{1} \mathrm{H}$ and ${ }^{13} \mathrm{C}$ NMR data in Tables 3 and 2; HRMS $m / z 371.2227\left[\mathrm{M}+\mathrm{H}-\mathrm{H}_{2} \mathrm{O}\right]^{+}$(calcd. for $\mathrm{C}_{23} \mathrm{H}_{31} \mathrm{O}_{4}{ }^{+}, 371.2217$ ).

Carneic acid $O(13):[\alpha]^{25}-112.0\left(c 0.1, \mathrm{CDCl}_{3}\right) ;{ }^{1} \mathrm{H}$ and ${ }^{13} \mathrm{C}$ NMR data in Tables 3 and 2; HRMS $m / z 371.2212\left[\mathrm{M}+\mathrm{H}-\mathrm{H}_{2} \mathrm{O}\right]^{+}$(calcd. for $\mathrm{C}_{23} \mathrm{H}_{31} \mathrm{O}_{4}{ }^{+}, 371.2217$ ).

Viral Polymerase Assays. Fractions and pure compounds from Phomopsis sp. were diluted in DMSO $100 \%$ at $1 \mathrm{mg} / \mathrm{mL}$ and tested on a DENV RNA-dependent RNA polymerase assay (DENV RdRp assay). The DENV RdRp bioassay has been described previously. ${ }^{17}$

Pure compounds from Phomopsis sp. were also evaluated against Zika virus. All samples were diluted in DMSO $100 \%$ at $1 \mathrm{mg} / \mathrm{mL}$ and tested in a Zika-NS5 assay by measurement of the relative polymerase activity. The compound concentration leading to $50 \%$ inhibition of Zika NS5-mediated RNA synthesis was determined in reaction buffer (50 mM HEPES pH 8.0, $10 \mathrm{mM}$ $\mathrm{KCl}, 2 \mathrm{mM} \mathrm{MnCl} 2,2 \mathrm{mM} \mathrm{MgCl} 2,10 \mathrm{mM}$ DTT) containing $100 \mathrm{nM}$ of homopolymeric uridine RNA template, $40 \mathrm{nM}$ of Zika NS5 and 7 concentrations of compound. Five ranges of inhibitor were available ( 0.01 to $5 \mu \mathrm{M} / 0,1$ to $50 \mu \mathrm{M} / 0,5$ to $50 \mu \mathrm{M} / 1$ to $100 \mu \mathrm{M} / 5$ to $400 \mu \mathrm{M}$ ) (Table 5). Reactions were conducted in a $40-\mu \mathrm{L}$ volume on a $96-$ well Nunc plate. All experiments were robotized by using a BioMek 3000 automate (Beckman). A volume of $2 \mu \mathrm{L}$ of each diluted compound in $100 \%$ DMSO was added to plate wells to the chosen concentration (5\% DMSO final concentration). For each assay, the enzyme mix was then distributed in the plate wells. Reactions were then started by the addition of the nucleotide mix (100 $\mu \mathrm{M} \mathrm{ATP)} \mathrm{and} \mathrm{were}$ 
incubated at $30^{\circ} \mathrm{C}$ for $10 \mathrm{~min}$. Reaction assays were stopped by the addition of $20 \mu 1$ of EDTA $100 \mathrm{mM}$.

Table 5. Range of Inhibitor and Concentrations in the $\mathrm{IC}_{50}$ Assay.

Range of inhibitor $(\mu \mathrm{M})$ Concentrations of inhibitor $(\mu \mathrm{M})$

\begin{tabular}{llllllll}
\hline $0.01-5$ & 0.01 & 0.05 & 0.1 & 0.2 & 0.5 & 1 & 5 \\
$0.1-50$ & 0.1 & 0.5 & 1 & 2 & 5 & 10 & 50 \\
$0.5-50$ & 0.5 & 1 & 2 & 5 & 10 & 20 & 50 \\
$1-100$ & 1 & 2 & 5 & 10 & 20 & 50 & 100 \\
$5-400$ & 5 & 10 & 20 & 50 & 100 & 200 & 400
\end{tabular}

Negative and positive controls consisted of a reaction mix with $5 \%$ DMSO final concentration or $100 \mathrm{mM}$ EDTA, respectively, in place of the compound.

Reaction mixes were then transferred to Greiner plate using a Biomek NX automate (Beckman). Picogreen ${ }^{\circledR}$ fluorescent reagent from Molecular Probes was diluted to $1 / 800^{\circ}$ in TE buffer according the manufacturer's recommendation, and $60 \mu 1$ of reagent was distributed into each well of the Greiner plate. The plate was incubated for $5 \mathrm{~min}$ in the dark at room temperature, and the fluorescence signal was then read at $480 \mathrm{~nm}$ (excitation) and $530 \mathrm{~nm}$ (emission) using a TecanSafire2. $\mathrm{IC}_{50}$ was determined using the equation $\%$ of active enzyme $=$ $100 /\left(1+(\mathrm{I})^{2} / \mathrm{IC}_{50}\right)$, where $\mathrm{I}$ is the concentration of inhibitor and $100 \%$ of activity is the fluorescence intensity without inhibitor. For each value, the results were obtained in triplicate in a single experiment.

Cell Culture and Proliferation Assay. The MRC-5 cell line derived from normal lung tissue was obtained from the American Type Culture Collection (Rockville, MD, USA) and was cultured according to the supplier's instructions. Human MRC-5 cells were grown in DMEM supplemented with $10 \%$ fetal calf serum (FCS) and $1 \%$ glutamine. Cells were maintained at 
$37{ }^{\circ} \mathrm{C}$ in a humidified atmosphere containing $5 \% \mathrm{CO}_{2}$. Living cells were determined by an MTS assay according to the manufacturer's instructions (Promega, Madison, WI, USA). Briefly, the cells were seeded in 96 -well plates $\left(2.5 \times 10^{3}\right.$ cells/well) containing $200 \mu$ l of growth medium. After $24 \mathrm{~h}$ of culture, the cells were treated with the tested compounds at $10 \mu \mathrm{M}$ final concentrations. After $72 \mathrm{~h}$ of incubation, $40 \mu \mathrm{l}$ of resazurin was added $2 \mathrm{~h}$ before recording the absorbance at $490 \mathrm{~nm}$ with a spectrophotometric plate reader. The percent of living cells was calculated from three experiments.

\section{ASSOCIATED CONTENT}

The Supporting Information is available free of charge on the ACS Publications website at DOI: Fractions antiviral activity and NMR $\left({ }^{1} \mathrm{H}, \mathrm{COSY}, \mathrm{HSQC}, \mathrm{HMBC}, \mathrm{ROESY}\right.$ or NOESY and $\left.{ }^{13} \mathrm{C}\right)$ and mass spectra for compounds 1-13 (DOCX).

The authors declare no competing financial interests.

\section{AUTHOR INFORMATION}

\section{Corresponding Authors}

*Tel: +33169823085, E-mail address: marc.litaudon@cnrs.fr (M. Litaudon).

*Tel: +33430192476, E-mail address: didier.stien@cnrs.fr (D. Stien).

\section{Author Contributions}

This manuscript was written with contributions from all authors. All authors have given approval of the final version of the manuscript.

\section{ACKNOWLEDGMENTS}


This work has benefited from an "Investissement d'Avenir" grant managed by Agence Nationale de la Recherche (CEBA, ref. ANR-10-LABX-25-01). We would like to express our appreciation to J.-F. Gallard, who performed NMR experiments.

\section{REFERENCES}

(1) Petrini, O. Fungal Endophytes of Tree Leaves. In Microbial Ecology of Leaves; Andrews, J. H., Hirano, S. S., Eds.; Springer: New York, NY, 1991; pp 179-197.

(2) Stierle, A.; Strobel, G.; Stierle, D. Science 1993, 260, 214-216.

(3) Kharwar, R. N.; Verma, V. C.; Kumar, A.; Gond, S. K.; Harper, J. K.; Hess, W. M.; Lobkovosky, E.; Ma, C.; Ren, Y.; Strobel, G. A. Curr. Microbiol. 2009, 58, 233-238.

(4) Kellogg, J. J.; Todd, D. A.; Egan, J. M.; Raja, H. A.; Oberlies, N. H.; Kvalheim, O. M.; Cech, N. B. J. Nat. Prod. 2016, 79, 376-386.

(5) Barthélémy, M.; Elie, N.; Pellissier, L.; Wolfender, J.-L.; Stien, D.; Touboul, D.; Eparvier, V. Int. J. Mol. Sci. 2019, 20, 2006.

(6) Casella, T. M.; Eparvier, V.; Mandavid, H.; Bendelac, A.; Odonne, G.; Dayan, L.; Duplais, C.; Espindola, L. S.; Stien, D. Phytochemistry 2013, 96, 370-377.

(7) Mandavid, H.; Rodrigues, A. M. S.; Espíndola, L. S.; Eparvier, V.; Stien, D. J. Nat. Prod. 2015, 78, 1735-1739.

(8) Calcul, L.; Waterman, C.; Ma, W. S.; Lebar, M. D.; Harter, C.; Mutka, T.; Morton, L.; Maignan, P.; Van Olphen, A.; Kyle, D. E.; Vrijmoed, L.; Pang, K.-L.; Pearce, C.; Bakeret, B. J. Mar. Drugs 2013, 11, 5036-5050. 
(9) Peyrat, L.-A.; Eparvier, V.; Eydoux, C.; Guillemot, J.-C.; Stien, D.; Litaudon, M. Fitoterapia 2016, 112, 9-15.

(10) Peyrat, L.-A.; Eparvier, V.; Eydoux, C.; Guillemot, J.-C.; Litaudon, M.; Stien, D. Chem. Biodivers. 2017, 14, e1600171.

(11) Udayanga, D.; Liu, X.; Mckenzie, E. H. C.; Chukeatirote, E.; Bahkali, A. H. A.; Hyde, K. D. Fungal Divers. 2011, 50, 189-225.

(12) Quang, D. N.; Stadler, M.; Fournier, J.; Asakawa, Y. J. Nat. Prod. 2006, 69, 1198-1202.

(13) Yamakoshi, S.; Hayashi, N.; Suzuki, T.; Nakada, M. Tetrahedron Lett. 2009, 50, 53725375.

(14) Kobayashi, H.; Meguro, S.; Yoshimoto, T.; Namikoshi, M. Tetrahedron 2003, 59, 455459.

(15) Namikoshi, M.; Kobayashi, H.; Yoshimoto, T.; Meguro, S.; Akano, K. Chem. Pharm. Bull. 2000, 48, 1452-1457.

(16) Kobayashi, H.; Sunaga, R.; Furihata, K.; Morisaki, N.; Iwasaki, S. J. Antibiot. 2012, 48, $42-52$.

(17) Benmansour, F.; Eydoux, C.; Querat, G.; de Lamballerie, X.; Canard, B.; Alvarez, K.; Guillemot, J.-C.; Barral, K. Eur. J. Med. Chem. 2016, 109, 146-156. 
Table of Contents (TOC)/Abstract Graphic

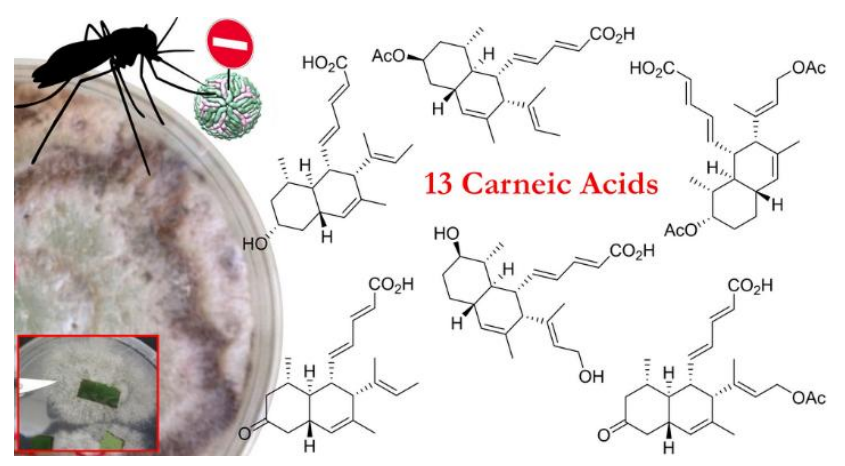

